\title{
Obstructive Sleep Apnea: New Concepts, Mechanism, and Therapy
}

\author{
${ }^{1}$ Sonam Spalgais, ${ }^{2}$ Dipti Gothi
}

\begin{abstract}
Continuous positive airway pressure (CPAP) is the gold standard for the management of obstructive sleep apnea (OSA). However, studies have shown that only around half use the device at the minimum recommended level of $\geq 4$ hours/night. The compliance further drops to $17 \%$ after 5 years. Thus, there is need to develop and apply new modalities for the OSA. Also, if the treatment of OSA is directed toward the mechanism, the results are likely to be better. This review is aimed at mechanismdirected treatment for OSA.
\end{abstract}

Keywords: Mechanism, Newer treatment, Obstructive sleep apnea.

How to cite this article: Spalgais S, Gothi D. Obstructive Sleep Apnea: New Concepts, Mechanism, and Therapy. Indian J Sleep Med 2017;12(4):64-72.

Source of support: Nil

Conflict of interest: None

\section{INTRODUCTION}

The mainstay of OSA treatment has been CPAP delivered by an interface to pneumatically splint open the airway to prevent collapse. Many patients are unable to tolerate and initiate CPAP treatment and of those who do, only half of them use the device at the minimum recommended level ( $\geq 4$ hours/night); ${ }^{1}$ furthermore this drops to $17 \%$ after 5 years of treatment. ${ }^{2}$ However, OSA is increasingly recognized as a heterogeneous disorder with multiple pathophysiological causes. Targeting OSA treatment to individual pathologies could broaden treatment options for the patient and improve patient acceptance, outcomes, and help move toward a future of a personalized medicine approach to treatment. ${ }^{3}$ The mechanisms are classified as anatomical mechanism, neuromuscular mechanisms, lung volume, ventilator control stability, low arousal threshold,

\footnotetext{
${ }^{1}$ Assistant Professor, ${ }^{2}$ Professor

${ }^{1}$ Vallabhbhai Patel Chest Institute, New Delhi, India

${ }^{2}$ Department of Pulmonary Medicine, Employees' State Insurance Post Graduate Institute of Medical Sciences \& Research, New Delhi, India

Corresponding Author: Dipti Gothi, Professor, Department of Pulmonary Medicine, Employees' State Insurance Post Graduate Institute of Medical Sciences \& Research, New Delhi India, e-mail: diptigothi@gmail.com
}

sleep-related decrease in lung volume, and fluid redistribution as well as upper airway surface tension. Thus, to make treatment more tailor-made and appropriate for a particular patient, new treatment based on pathogenesis and phenotypes have emerged. In this review, we discuss various personalized treatment strategies for OSA as per various pathophysiology and phenotypes.

\section{Mechanisms}

\section{Anatomical Mechanism}

The OSA patients tend to have smaller pharyngeal airways, with a narrower cross-sectional area of the airway lumen, which is more collapsible. ${ }^{4,5}$ This is attributed by the surrounding structure including upper airway soft tissues, regional adipose tissue, and the craniofacial skeleton. The collapsing pressure from surrounding pharyngeal tissues is generated by the interaction of pharyngeal soft tissues and the surrounding craniofacial skeletal. ${ }^{6}$ Starling Resistor model explained that excess tissue within the bony enclosure must be present to generate sufficient tissue pressure to collapse the airway lumen. This extraluminal tissue pressure can be achieved by either an excess of soft tissue within a normal bony enclosure or by a normal amount of tissue compressed into a reduced enclosure. ${ }^{6,7}$ Another anatomical mechanism in OSA is position dependency. The supine posture of body is associated with more as well as worsening of obstructive respiratory events. The upper airway is more collapsible in the supine than in lateral position and this may relate to effects of body position and gravity on airway geometry, upper airway dilator muscle responsiveness, and lung volume. ${ }^{3,8,9}$ The various treatment options for the above mechanism of OSA are mandibular advancement devices (MADs), pillar, weight reduction, upper airway surgeries, and positional therapy.

\section{Neuromuscular Mechanisms}

The patency of the upper airway depends on the muscular work coordinated between the pharyngeal dilator muscles and the inspiratory muscles. The most important muscle is the genioglossus. ${ }^{7,10}$ The upper airway dilator muscle activity is regulated by chemoreceptors, mechanoreceptors, and baroreceptors that detect the 
type of change within the upper airway. ${ }^{11,12}$ The genioglossus muscle activation is negatively correlated with upper airway collapsibility and pharyngeal resistance. ${ }^{13}$ The OSA patients have increased dilator muscle activity during wakefulness, suggesting that a neuromuscular compensatory mechanism exists to counteract collapsing forces. ${ }^{14}$ The increase in dilator muscle activity helps to stabilize the airway during the event of negative intraluminal suction pressure which would otherwise make the airway vulnerable to closure. This negative pressure reflex appears to be stronger in OSA patients in the wakeful state. ${ }^{15}$ Therefore, the disturbances in upper airway dilator muscle control are clearly a pathogenic mechanism in OSA patients. The treatment options of OSA with neuromuscular mechanisms are hypoglossal nerve stimulation (HNS), oropharyngeal exercise, and serotonergic/cholinergic drugs.

\section{Role of Lung Volume}

The upper airway structure and function are also influenced by lung volume. Lung volume falls with sleep and in recombinant position. ${ }^{16}$ The increased lung volume improves upper airway patency, reduces collapsibility, airflow resistance, and increases pharyngeal cross-sectional area. ${ }^{17-19}$ Furthermore, increased lung volume in OSA patients reduces therapeutic CPAP pressure requirement. ${ }^{18}$ Therefore, reduced lung volumes negatively impact on airway patency and contribute to sleep disordered breathing. The primary effect of lung volume on the upper airway may be through mechanical effects by caudal traction that leads to stiffening of upper airway structures. Tracheal traction via mechanical linkage to mediastinal structures in response to increasing lung volume and intrathoracic pressure improves upper airway patency and resistance. ${ }^{20,21}$ This increased lung volume also results in caudal traction on the trachea, which increases the pharyngeal lumen size and decreases pharyngeal extraluminal tissue pressure, which may be mediated through caudal movement of the hyoid bone.7,22 The obese OSA patients have a greater reduction in end expiratory lung volume and diaphragm activity at sleep. Reduced lung volume secondary to obesity may contribute to increased propensity of upper airway collapse. Nasal expiratory positive airway pressure (nEPAP) and weight reduction are treatment option to treat OSA with etiological mechanism of reduced lung volume.

\section{Ventilatory Control Mechanisms}

The neuronal output of respiratory center controls breathing to maintain optimal levels of oxygen and $\mathrm{CO}_{2}$; however, instability in this control system may lead to periods of cyclic breathing and an obstructed airway. ${ }^{23}$ It has been well documented that there is greater instability of the ventilatory control system among the OSA patients. ${ }^{24,25}$ The chemoreceptor control system, therefore, plays an important role in determining whether obstructive events are followed by unstable breathing, which further exacerbates the problem. ${ }^{26}$ The ventilatory instability has been described in terms of "loop gain" which describes the stability of a negative feedback control system in terms of the ratio of the response to a given disturbance. ${ }^{27,28}$ The important components of loop gain in control of breathing are chemoresponsiveness of the system. High loop gain reflects an excessive reaction to a disturbance which ultimately leads to instability and fluctuations of hyper- and hypoventilation, ${ }^{23}$ while low loop gain reflects a more controlled response to perturbation and ultimately more stable breathing. The strongest correlation between loop gain and apnea/hypopnea index (AHI) occurs in those with a relatively less collapsible airway. ${ }^{25}$ So, the instability of ventilatory control, or high loop gain, is an important pathogenic mechanism in OSA patients. The OSA patients with this mechanism benefit when treated with oxygen therapy and respiratory stimulant like acetazolamide.

\section{Role of Arousal Threshold}

The obstructive events are generally terminated by arousal from sleep leading to airway opening. So, arousals have been considered a protective event, which terminates apnea and resumes airflow. However, a respiratory event can be terminated without involving an arousal and other neuromuscular and respiratory compensatory mechanisms can increase dilator muscle activity in response to obstruction and open the airway. ${ }^{29,30}$ In some cases, termination of a respiratory event with an arousal can be unfavorable, with airway opening and subsequent decrease in airway resistance, leading to hyperventilation and hypocapnia. ${ }^{29,31}$ As a result, it reduces upper airway dilator muscle activation, leading to further airway collapse and $\mathrm{CO}_{2}$ level may decrease below the apnea threshold. ${ }^{32,33}$ An arousal occurs before there is time for physiological signals from $\mathrm{CO}_{2}$ and negative pressure to accumulate and activate dilator muscles and ongoing ventilatory instability occurs in OSA patients due to low arousal threshold. ${ }^{26}$ Few studies have shown that patients of OSA with arousal threshold mechanism may benefit more, when treated with non-benzodiazepine sedatives like eszopiclone and zopiclone.

\section{Role of Surface Tension}

The adhesive forces between the mucosal surfaces of the upper airway contribute to collapse and high surface tension, which further opposes reopening of the upper airway following closure. ${ }^{3}$ The exogenous surfactant 
improves upper airway patency by reducing surface tension and improved closing pressures of almost $2 \mathrm{~cm}$ $\mathrm{H}_{2} \mathrm{O} .{ }^{34}$ It was shown that in OSA patients, the upper airway lining liquid has a higher surface tension. ${ }^{35}$ Therefore, surface tension of the upper airway mucosa may facilitate or protect the upper airway from collapsing in individuals. ${ }^{3,36}$ So, patients with OSA of this phenotype are better with exogenous surfactant and nasal breathing in combination with other therapies.

\section{Role of Rostral Fluid Shift}

The observation of high prevalence of OSA in patients with fluid retaining states, such as heart and renal failure leads to the role of nocturnal rostral fluid shift in the pathogenesis of sleep apnea. ${ }^{37,38}$ The concept being that, during the day, when the body is predominantly in upright position causes fluid to pool in lower limbs; however, during night in the supine position, gravity acts to move the accumulated leg fluid rostrally and subsequently increase the neck region fluid volume. It leads to increase in tissue pressure and collapsibility of the pharyngeal airway. It has been observed in studies that application of lower body positive pressure results in an increase in neck circumference and decrease in cross-sectional area of the pharyngeal airway, increases in resistance and overall increase in collapsibility. ${ }^{39,40}$ The increase in pharyngeal resistance in response to lower body positive pressure is greater in OSA compared with non-OSA patients. ${ }^{41}$ The shifting of overnight fluid from the legs to the neck is strongly correlated with AHI in OSA patients. ${ }^{42}$ However, the differences in the effect of fluid shift on OSA and lower body positive pressure on upper airway collapsibility were more in male than in female patients. ${ }^{43,44}$ The different pattern of rostral fluid movement between male and female may be one mechanism that explains the gender difference in OSA prevalence. The treatment options for patients with this mechanism of OSA are compression stockings, exercise and diuretics in combination with CPAP and others. The overall various mechanism of OSA with their treatment options is summarized in Table 1.

\section{Newer Treatment Options}

\section{Mandibular Advancement Devices}

One of the new treatment options for OSA patient is MAD. The MAD is an oral appliance, which holds the jaw in a forward position during sleep. This jaw adjustment causes upper displacement of hyoid bone, lateral displacement of parapharyngeal fat pads, and anterior movement of the muscles of the base of tongue. So, MAD increases the size of the upper airway space, increases neuromuscular activation of upper airway and decreases extraluminal tissue pressure. ${ }^{45,46}$ The MAD decreases in AHI and symptoms of sleepiness in OSA. However, MAD is more effective in patients with following characteristics, such as, mildto-moderate OSA, young age, female gender, small neck size, retrognathic jaw, and low body mass index (BMI). ${ }^{47-49}$ The American Academy of Sleep Medicine and American Academy of Dental Sleep Medicine recommended MAD for OSA patients, who are intolerant/noncompliance with CPAP therapy. ${ }^{50}$ The MAD is a US Food and Drug Administration (FDA)-approved treatment option for patients OSA with noncompliance/intolerant to CPAP treatment. MAD are less effective for patients with morbid obesity (BMI>40), steep mandibular plane, long neck, poor dentition, and acute temporomandibular joint dysfunction. The adverse effects commonly seen with MAD are temporomandibular syndrome, tooth pain and myofascial pain, excessive salivation, dryness of the mouth, overbite, and reduction of the protrusion. ${ }^{3,49,51}$ Overall, MAD is less effective than CPAP therapy to treat OSA patients. However, the efficacy of the MAD may come to similar to CPAP due to its better adherence rate. ${ }^{7,52-54}$

Table 1: Possible various mechanism and their treatment options

\begin{tabular}{|c|c|c|}
\hline Mechanism of OSA & Possible etiologies & Treatment options \\
\hline Anatomical & $\begin{array}{l}\text { Narrow, small, and collapsible upper airway, obesity, } \\
\text { adipose tissue deposition, enlargement of soft tissues, } \\
\text { and craniofacial bony abnormalities }\end{array}$ & $\begin{array}{l}\text { Mandibular advancement devices, pillar, } \\
\text { weight reduction, upper airway surgeries, } \\
\text { positional therapy }\end{array}$ \\
\hline Neuromuscular & $\begin{array}{l}\text { Decreases in upper airway dilator muscle tone and } \\
\text { reflexes, coordination of dilator and inspiratory muscles, } \\
\text { and receptor regulatory muscular activity }\end{array}$ & $\begin{array}{l}\text { Hypoglossal nerve stimulation, oropharyngeal } \\
\text { exercise, and serotonergic/cholinergic drugs }\end{array}$ \\
\hline Lung volume & Mechanical effect of traction, supine position and obesity & $\begin{array}{l}\text { Nasal expiratory positive airway pressure and } \\
\text { weight reduction }\end{array}$ \\
\hline Ventilatory control & $\begin{array}{l}\text { Loop gain mechanism: Instability of ventilator control } \\
\text { system, receptor regulatory in changes to } \mathrm{O}_{2} \text { and } \mathrm{CO}_{2} \\
\text { concentration }\end{array}$ & Oxygen therapy and acetazolamide \\
\hline Low arousal threshold & Awakening in response to obstructive events & Eszopiclone and zopiclone \\
\hline Rostral fluid shift & Fluid retention state and positional shifting of fluid & Compression stockings, exercise, and diuretics \\
\hline Surface tension & High surface tension of upper airway liquid lining & Surfactant and nasal breathing \\
\hline
\end{tabular}




\section{Pillar Procedure}

Pillar is an implant used for the treatment mild and moderate OSA. The pillar procedure is a minimally invasive palatal stiffening technique, usually performed under local anesthesia. It consists of three pieces of polyethylene, which are inserted in a parallel fashion in the soft palate. This causes a chronic inflammatory response that creates a fibrous capsule around them to add structural support, harden the soft palate, and leads to reduced airway vibration and collapse. $7,55,56$ There is reduction in AHI, the intensity of snoring, and daytime excessive sleepiness with pillar implant treatment. The effectiveness is more in the patients who do significant palatal component to OSA. ${ }^{57,58}$ The risk of postoperative complications and other morbidities is low, as it is a minimally invasive procedure. Patients with lower preoperative BMI and AHI have better long-term response rate..$^{59-61}$ So, pillar implant is one of good treatment options for patient of OSA who refuse or fail CPAP therapy.

\section{Pharmacotherapy for Weight}

Nearly 60 to $70 \%$ of OSA patients are overweight, and about $58 \%$ of moderate-to-severe OSA cases are attributable to excess weight. ${ }^{62-64}$ Weight loss has been shown to reduce severity of OSA, improve oxygen saturation, quality of life, and sleep parameters. ${ }^{62,65,66}$ The beneficial effects of weight loss persist over the long term despite weight regain in OSA patients. ${ }^{67,68}$ The clinical practice guidelines recommend weight loss for OSA patients with excess weight. ${ }^{69,70}$ Liraglutide is a glucagon-like peptide-1 receptor agonist that was initially approved by the FDA management of type 2 diabetes. ${ }^{62,71}$ Liraglutide has recently received approval for weight loss agent at the dose of $3.0 \mathrm{mg}$ once daily. ${ }^{62,72}$ The mechanism of action of liraglutide is through appetite suppression, delayed gastric emptying with a subsequent decrease in energy intake. ${ }^{62,72,73}$ Blackman et $\mathrm{al}^{62}$ in a study have shown that liraglutide $3 \mathrm{mg}$ once daily significantly decreases AHI, body weight, systolic blood pressure, and hemoglobin A1c compared with placebo over 32 weeks. Liraglutide is generally well tolerated with transient mild-to-moderate adverse effects. The common adverse effects are gastrointestinal and include diarrhea, constipation, dyspepsia, vomiting, and nausea. The other adverse effects include headache, increase in pulse rate, nasopharyngitis, and increase in lipase. ${ }^{62,72}$ Liraglutide is more effective in patients who refused or CPAP failures with moderate-tosevere OSA with adjunct to diet and exercise. So, weight reduction with liraglutide is one of new treatment options for OSA patients; however, further studies are require for the duration of treatment and long-term benefit of this drug.

\section{Hypoglossal Nerve Stimulation}

The loss of genioglossus muscle activity during sleep leads to upper airway obstruction in OSA patients. The direct electric stimulation of the genioglossus via intraoral, intramuscular, or submental electrodes is able to dilate the upper airway, and increase airflow, decrease AHI, but also induce sleep arousals and fragmentation. ${ }^{74,75}$ To minimize the adverse events and to be a more effective method, a method of electric stimulation of the hypoglossal nerve is being implemented. The HNS electrically stimulates the hypoglossal nerve, a motor nerve innervating the protrusor, and retractor muscle of the tongue through eletrodes. ${ }^{76-78}$ The electrode is made of platinum/iridium, with tripolar design that distributes the current uniformly and avoids nerve damage. The leads of the stimulating electrodes are tunneled via the neck to a neurostimulator placed subcutaneous in chest. ${ }^{79,80}$ Studies have shown that there is significant improvement in symptoms of sleepiness, mood, quality of life, and reduction in AHI with HNS. ${ }^{76,77,79,81,82}$ Various trials have shown that there is significant decrease in AHI with HNS and is maintained for more than 3 years after implantation. ${ }^{76,77,81-84}$ The HNS is a US FDA-approved treatment option for patients with OSA, who are unable to use or not consistently benefiting from CPAP therapy. It has been shown that HNS had no therapeutic effect in high BMI patients. ${ }^{77,79}$ The HNS is a surgically invasive procedure with few serious adverse events, such as infection at the site of procedure and malfunctioning of neurostimulator. The other minor adverse events are numbness, pain, swelling at incision site, and temporary tongue weakness. ${ }^{76,77,79}$

\section{Nasal Expiratory Positive Airway Pressure}

Increasing lung volume has beneficial effects in decreasing AHI. The CPAP therapy leads to increase in lung volume and further lung volume increase has an additive effect in reducing AHI. ${ }^{85}$ Expiratory positive pressure has been investigated as a more practical means to increase end expiratory lung volume and thereby improve OSA. The highest risk of upper airway collapse occurs at the end of the expiratory phase because of a lack of positive pressure or phasic activation of the upper airways. ${ }^{86}$ The nEPAP is a system that creates high resistance during expiration but not during inspiration through small mechanical valves placed with adhesives in each nostril. ${ }^{87}$ Riaz et $\mathrm{al}^{88}$ in a meta-analysis of 18 studies have shown that there was a $53.2 \%$ decrease in AHI and an improvement in the quality of life; however, nEPAP did not entirely eliminate OSA and adherence is still an issue like CPAP therapy. The nEPAP benefits more in patients who are intolerant of CPAP or are traveling. It is not a good 
option for patients with hypercapnia respiratory failure, respiratory muscle weakness, bullous lung disease, and pneumothorax..$^{88,89}$

\section{Positional Therapy}

It is a known fact that supine position doubles a patient's AHI compared with lateral position sleeping. ${ }^{90}$ In a recent analysis, it is shown that $60 \%$ of patients were supinepredominant OSA. ${ }^{91}$ In a drug-induced endoscopy study, it has been shown that the upper airway collapses at multiple levels in the supine position as compared with at a single level in the lateral position. ${ }^{92}$ The various positional therapies include attaching a tennis ball to the neck, sleep hygiene, and night shift. Studies have shown that positional therapy significantly decreases AHI, but longterm compliance is still an issue. ${ }^{7,54} \mathrm{Night}$ shift is a recent device that consists of a small electronic monitor attached to the lower part of the neck before falling to sleep. When the patient changes position to the supine, the night shift begins to vibrate slowly and increases in intensity until a position change occurs. ${ }^{93}$ It has been shown that there is greater reduction in $\mathrm{AHI}$ and improvement of sleep architecture with night shift compared with other types of positional therapy. ${ }^{94,95}$ So, positional therapy is effective only in subset of OSA patients with positional OSA and also in combination with measures like oral appliance therapy and CPAP.

\section{Pharmacologic Treatment for reducing Loop Gain/reducing Arousal and decreasing Surface Tension}

Many pharmacological agents are tried in treatment of OSA; however, no single drug is approved for OSA treatment till date. In a recent Cochrane review, various drugs were assessed for treating OSA. These drugs are: Increasing ventilatory drive (like, acetazolamide, theophylline, and progestogens), increasing upper airway tone (like serotonergics and cholinergics), decreasing rapid eye movement (REM) sleep (like clonidine and antidepressants), increasing arousal threshold (like eszopiclone and zopiclone), and increasing the crosssectional area or reducing the surface tension of the upper airway (like fluticasone and lubricant). This review concluded that there is some benefit with few drugs; however, their adverse events need to be considered. While there is no or little benefit with some drugs on AHI, even if they have effect on OSA, adverse effects are more than benefits. ${ }^{96}$ The commonly used pharmacological agents for treatment of OSA or in clinical trial are the following:

Eszopiclone: A non-benzodiazepine sedative, used to increase arousal threshold without effecting genioglossus activity. ${ }^{96}$ However, the studies have shown that there is increase in respiratory arousal threshold, but had no effect on AHI, and increased oxygen desaturation. ${ }^{54,96,97}$

Acetazolamide: It is a respiratory stimulant acting via inhibition of carbonic anhydrase inhibition. Carbonic anhydrase inhibitors are used to stabilize the ventilatory control system by a decrease in high loop gain. Studies have shown that acetazolamide decreased loop gain, decreased AHI in non-REM (NREM) sleep. There is a need for larger randomized study for further evaluation of this drug in OSA treatment. ${ }^{98,99}$

Dronabinol: Nonselective cannabinoid type 1 and type 2 receptor agonist. It significantly reduced AHI and improved subjective sleepiness and alertness. ${ }^{100,101}$ Dronabinol most likely acts through increases in upper airway tone though inhibition of vagal nerve. ${ }^{54,102}$ Minor adverse events of this drug are somnolence and increased appetite. ${ }^{101}$ Further larger randomized studies will be needed to establish the safety and efficacy of dronabinol in the treatment of OSA.

Treatment Combinations and Phenotyping: Many OSA patients have more than one mechanism. Combination of two or more treatments might lead to greater decreases in AHI and greater improvements in OSA symptoms. ${ }^{103,104}$ The combination of an oral appliance and positional therapy led to further significant decreases in AHI compared with single-agent treatments. ${ }^{54,105}$ To correctly combine these treatment options, the patient will have to be specifically phenotyped via polysomnography to differentiate and specify the pathophysiology of OSA. There are published methods of OSA mechanism phenotyping according to patient's sleep position, ventilation parameters, loop gain, arousal threshold, and upper airway gain, and if apneic events occur in REM or NREM sleep. ${ }^{92,106}$ The various treatment options according to pathophysiology of OSA with their advantages and disadvantages are summarized in Table 2.

\section{CONCLUSION}

The OSA is a heterogeneous disorder with different mechanisms that lead to collapse of upper airway. Rigorous evaluation to find out the exact mechanism or combination of mechanism seems to be most appropriate treatment. As phenotypic base treatment options are well tolerated and have more adherence, it leads to better long-term outcome. The various newer therapies that are now widely used are mandibular advancement device, pillar procedure, HNS, increasing expiratory volume, and positional device. Combination therapy with two or more devices may be useful in certain patients. 
Table 2: Various newer treatment options with their advantages and disadvantages

\begin{tabular}{|c|c|c|}
\hline Treatment & Advantages & Disadvantages \\
\hline $\begin{array}{l}\text { Mandibular } \\
\text { advancement } \\
\text { devices }\end{array}$ & $\begin{array}{l}\text { Reduces extraluminal pressure at the oropharyngeal } \\
\text { level } \\
\text { Activates the upper airway musculature } \\
\text { Better adherences than CPAP } \\
\text { More effective in females, small neck size, low BMI, } \\
\text { and retrognathic jaw }\end{array}$ & $\begin{array}{l}\text { Overall less effective than CPAP } \\
\text { Dental alterations: Pain, overbite, protrusion reduction } \\
\text { Temporomandibular syndrome } \\
\text { Myofascial pain } \\
\text { Excessive salivation } \\
\text { Dryness of oral mucous membrane }\end{array}$ \\
\hline nEPAP & $\begin{array}{l}\text { Greater adherence than CPAP } \\
\text { Inexpensive } \\
\text { Better for travelers } \\
\text { Noninvasive }\end{array}$ & $\begin{array}{l}\text { Poor adherence } \\
\text { Not entirely eliminates OSA } \\
\text { Not good option for patients with hypercapnic respiratory } \\
\text { failure, pneumothorax, and bullous lung }\end{array}$ \\
\hline Pillar & $\begin{array}{l}\text { Minimal invasive } \\
\text { More effective in OSA with palatal component } \\
\text { More effective in mild-to-moderate OSA with low BMI }\end{array}$ & $\begin{array}{l}\text { Discomfort with deglutition } \\
\text { Ineffective with retropalatal obstruction } \\
\text { Operative procedure } \\
\text { Postoperative complications }\end{array}$ \\
\hline $\begin{array}{l}\text { Hypoglossal nerve } \\
\text { stimulation }\end{array}$ & $\begin{array}{l}\text { Only treatment that attempts to eliminate OSA } \\
\text { Increases inspiratory airflow }\end{array}$ & $\begin{array}{l}\text { Invasive procedure } \\
\text { Not effective in high BMI patients } \\
\text { May have secondary effects like: Paralysis of the phrenic } \\
\text { nerve, muscle fatigue, changes in the type of muscle } \\
\text { fiber, soft tissue abrasion, and hypertrophy of lingual } \\
\text { musculature }\end{array}$ \\
\hline Positional therapy & $\begin{array}{l}\text { Shown to be the most effective for positional OSA } \\
\text { Can be easily used in combination } \\
\text { Noninvasive }\end{array}$ & Sleep disruption at the beginning of treatment \\
\hline Liraglutide & $\begin{array}{l}\text { More effective in obese } \\
\text { Can be used in combination with other treatment }\end{array}$ & $\begin{array}{l}\text { Injectable } \\
\text { Gastrointestinal adverse effects } \\
\text { Duration of treatment }\end{array}$ \\
\hline
\end{tabular}

\section{REFERENCES}

1. Bartlett D, Wong K, Richards D, Moy E, Espie CA, Cistulli PA, Grunstein R. Increasing adherence to obstructive sleep apnea treatment with a group social cognitive therapy treatment intervention: a randomized trial. Sleep 2013 Nov;36(11): 1647-1654.

2. Weaver TE, Sawyer A. Management of obstructive sleep apnea by continuous positive airway pressure. Oral Maxillofac Surg Clin North Am 2009;21(4):403-412.

3. Suthrland K, Cistulli PA. Recent advances in obstructive sleep apnea pathophysiology and treatment. Sleep Biol Rhythms 2015;13:26-40.

4. Suratt PM, Dee P, Atkinson RL, Armstrong P, Wilhoit SC. Fluoroscopic and computed tomographic features of the pharyngeal airway in obstructive sleep apnea. Am Rev Respir Dis 1983 Apr;127(4):487-492.

5. Lam B, Ooi CG, Peh WC, Lauder I, Tsang KW, Lam WK, Ip MS. Computed tomographic evaluation of the role of craniofacial and upper airway morphology in obstructive sleep apnea in Chinese. Respir Med 2004 Apr;98(4):301-307.

6. Watanabe $\mathrm{T}$, Isono S, Tanaka A, Tanzawa H, Nishino T. Contribution of body habitus and craniofacial characteristics to segmental closing pressures of the passive pharynx in patients with sleep-disordered breathing. Am J Respir Crit Care Med 2002 Jan 15;165(2):260-265.

7. Reyes EC, Bermúdez KP, Córdoba FE. New perspectives in the treatment of obstructive sleep apnea-hypopnea syndrome. Rev Colomb Anestesiol 2017;45(1):62-71.

8. Joosten SA, O'Driscoll DM, Berger PJ, Hamilton GS. Supine position related obstructive sleep apnea in adults: pathogenesis and treatment. Sleep Med Rev 2014 Feb;18(1):7-17.
9. Ong JS, Touyz G, Tanner S, Hillman DR, Eastwood PR, Walsh JH. Variability of human upper airway collapsibility during sleep and the influence of body posture and sleep stage. J Sleep Res 2011 Dec;20(4):533-537.

10. Patil SP, Schneider H, Schwartz AR, Smith PL. Adult obstructive sleep apnea: pathophysiology and diagnosis. Chest 2007 Jul;132(1):325-337.

11. Lo YL, Jordan AS, Malhotra A, Wellman A, Heinzer RA, Eikermann M, Schory K, Dover L, White DP. Influence of wakefulness on pharyngeal airway muscle activity. Thorax 2007 Sep;62(9):799-805.

12. Jordan AS, White DP. Pharyngeal motor control and the pathogenesis of obstructive sleep apnea. Respir Physiol Neurobiol 2008 Jan 1;169(1):1-7.

13. Pierce R, White D, Malhotra A, Edwards JK, Kleverlaan D, Palmer L, Trinder J. Upper airway collapsibility, dilator muscle activation and resistance in sleep apnoea. Eur Respir J 2007 Aug;30(2):345-353.

14. Mezzanotte WS, Tangel DJ, White DP. Waking genioglossal electromyogram in sleep apnea patients versus normal controls (a neuromuscular compensatory mechanism). J Clin Invest 1992 May;89(5):1571-1579.

15. Berry RB, White DP, Roper J, Pillar G, Fogel RB, Stanchina M, Malhotra A. Awake negative pressure reflex response of the genioglossus in OSA patients and normal subjects. J Appl Physiol 2003 May;94(5):1875-1882.

16. Ballard RD, Irvin CG, Martin RJ, Pak J, Pandey R, White DP. Influence of sleep on lung volume in asthmatic patients and normal subjects. J Appl Physiol 1990 May;68(5):2034-2041.

17. Owens RL, Malhotra A, Eckert DJ, White DP, Jordan AS. The influence of end-expiratory lung volume on measurements of pharyngeal collapsibility. J Appl Physiol 2010 Feb;108(2):445-451. 
18. Heinzer RC, Stanchina ML, Malhotra A, Fogel RB, Patel SR, Jordan AS, Schory K, White DP. Lung volume and continuous positive airway pressure requirements in obstructive sleep apnea. Am J Respir Crit Care Med 2005 Jul;172(1):114-117.

19. Series F, Cormier Y, Desmeules M. Influence of passive changes of lung volume on upper airways. J Appl Physiol 1990 May;68(5):2159-2164.

20. Van de Graaff WB. Thoracic influence on upper airway patency. J Appl Physiol 1988 Nov;65(5):2124-2131.

21. Van de Graaff WB. Thoracic traction on the trachea: mechanisms and magnitude. J Appl Physiol 1991 Mar;70(3): 1328-1336.

22. Kairaitis K, Byth K, Parikh R, Stavrinou R, Wheatley JR, Amis TC. Tracheal traction effects on upper airway patency in rabbits: the role of tissue pressure. Sleep $2007 \mathrm{Feb} ; 30(2)$ : 179-186.

23. Dempsey JA, Veasey SC, Morgan BJ, O’Donnell CP. Pathophysiology of sleep apnea. Physiol Rev 2010 Jan;90(1):47-112.

24. Younes M, Ostrowski M, Thompson W, Leslie C, Shewchuk W. Chemical control stability in patients with obstructive sleep apnea. Am J Respir Crit Care Med 2001 Apr;163(5):1181-1190.

25. Wellman A, Jordan AS, Malhotra A, Fogel RB, Katz ES, Schory K, Edwards JK, White DP. Ventilatory control and airway anatomy in obstructive sleep apnea. Am J Respir Crit Care Med 2004 Dec;170(11):1225-1232.

26. Younes M. Role of respiratory control mechanisms in the pathogenesis of obstructive sleep disorders. J Appl Physiol 2008 Nov;105(5):1389-1405.

27. Wellman A, Malhotra A, Jordan AS, Stevenson KE, Gautam S, White DP. Effect of oxygen in obstructive sleep apnea: role of loop gain. Respir Physiol Neurobiol 2008 Jul 31;162(2):144-151.

28. Campana L, Eckert DJ, Patel SR, Malhotra A. Pathophysiology \& genetics of obstructive sleep apnoea. Indian J Med Res 2010 Feb;131:176-187.

29. Younes M. Role of arousals in the pathogenesis of obstructive sleep apnea. Am J Respir Crit Care Med 2004 Mar;169(5): 623-633.

30. Jordan AS, Wellman A, Heinzer RC, Lo YL, Schory K, Dover L, Gautam S, Malhotra A, White DP. Mechanisms used to restore ventilation after partial upper airway collapse during sleep in humans. Thorax 2007 Oct;62(10):861-867.

31. Jordan AS, Eckert DJ, Catcheside PG, McEvoy RD. Ventilatory response to brief arousal from non-rapid eye movement sleep is greater in men than in women. Am J Respir Crit Care Med 2003 Dec;168(12):1512-1519.

32. Dempsey JA. Crossing the apnoeic threshold: causes and consequences. Exp Physiol 2005 Jan;90(1):13-24.

33. Rowley JA, Zhou XS, Diamond MP, Badr MS. The determinants of the apnea threshold during NREM sleep in normal subjects. Sleep 2006 Jan;29(1):95-103.

34. Kirkness JP, Madronio M, Stavrinou R, Wheatley JR, Amis TC. Relationship between surface tension of upper airway lining liquid and upper airway collapsibility during sleep in obstructive sleep apnea hypopnea syndrome. J Appl Physiol 2003 Nov;95(5):1761-1766.

35. Kirkness JP, Madronio M, Stavrinou R, Wheatley JR, Amis TC. Surface tension of upper airway mucosal lining liquid in obstructive sleep apnea/hypopnea syndrome. Sleep 2005 Apr;28(4):457-463.

36. Schwartz AR, Schneider H, Smith PL. Upper airway surface tension: is it a significant cause of airflow obstruction during sleep? J Appl Physiol 2003 Nov;95(5):1759-1760.
37. Ahmad S, Gupta M, Gupta R, Dhyani M. Prevalence and correlates of insomnia and obstructive sleep apnea in chronic kidney disease. North Am J Med Sci 2013 Nov;5(11):641-646.

38. Ferrier K, Campbell A, Yee B, Richards M, O'Meeghan T, Weatherall M, Neill A. Sleep-disordered breathing occurs frequently in stable outpatients with congestive heart failure. Chest 2005 Oct;128(4):2116-2122.

39. Shiota S, Ryan CM, Chiu KL, Ruttanaumpawan P, Haight J, Arzt M, Floras JS, Chan C, Bradley TD. Alterations in upper airway cross-sectional area in response to lower body positive pressure in healthy subjects. Thorax 2007 Oct;62(10):868-872.

40. Su MC, Chiu KL, Ruttanaumpawan P, Shiota S, Yumino D, Redolfi S, Haight JS, Bradley TD. Lower body positive pressure increases upper airway collapsibility in healthy subjects. Respir Physiol Neurobiol 2008 May;161(3):306-312.

41. White LH, Motwani S, Kasai T, Yumino D, Amirthalingam V, Bradley TD. Effect of rostral fluid shift on pharyngeal resistance in men with and without obstructive sleep apnea. Respir Physiol Neurobiol 2014 Feb;192:17-22.

42. Redolfi S, Yumino D, Ruttanaumpawan P, Yau B, Su MC, Lam J, Bradley TD. Relationship between overnight rostral fluid shift and Obstructive Sleep Apnea in nonobese men. Am J Respir Crit Care Med 2009 Feb;179(3):241-246.

43. Kasai T,MotwaniSS, Yumino D, MakS, Newton GE, Bradley TD. Differing relationship of nocturnal fluid shifts to sleep apnea in men and women with heart failure. Circ Heart Fail 2012 Jul;5(4):467-474.

44. Su MC, Chiu KL, Ruttanaumpawan P, Shiota S, Yumino D, Redolfi S, Haight JS, Yau B, Lam J, Bradley TD. Difference in upper airway collapsibility during wakefulness between men and women in response to lower-body positive pressure. Clin Sci 2009 May;116(9):713-720.

45. Sutherland K, Vanderveken OM, Tsuda H, Marklund M, Gagnadoux F, Kushida CA, Cistulli PA. Oral appliance treatment for obstructive sleep apnea: an update. J Clin Sleep Med 2014 Feb;10(2):215-227.

46. Chan AS, Sutherland K, Schwab RJ, Zeng B, Petocz P, Lee RW, Darendeliler MA, Cistulli PA. The effect of mandibular advancement on upper airway structure in obstructive sleep apnoea. Thorax 2010 Aug;65(8):726-732.

47. Browm EC, Cheng S, Mckenzie DK, Butler JE, Gandevia SC, Bilston LE. Tongue and lateral upper airway movement with mandibular advancement. Sleep 2013 Mar;36(3):397-404.

48. Zhu Y, Long H, Jian F, Lin J, Zhu J, Gao M, Lai W. The effectiveness of oral appliances for obstructive sleep apnea syndrome: a meta-analysis. J Dent 2015 Dec;43(12):1394-1402.

49. Correa LP. Overview of oral appliance therapy for management of obstructive sleep apnea. Sleep Med Clin 2013;8: 505-516.

50. Ramar K, Dort LC, KatzSG, Lettieri CJ,Harrod CG, Thomas SM, Chervin RD. Clinical practice guideline for the treatment of obstructive sleep apnea and snoring with oral appliance therapy: an update for 2015. J Clin Sleep Med 2015 Jul;11(7):773-827.

51. Doff MH, Finnema KJ, Hoekema A, Wijkstra PJ, Stengenga B. Long-term oral appliance therapy in obstructive sleep apnea syndrome: a controlled study on dental side effects. Clin Oral Investig 2013 Mar;17(2):475-482.

52. Phillips CL, Grunstein RR, Darendeliler MA, Mihailidou AS, Srinivasan VK, Yee BJ, Marks GB, Cistulli PA. Health outcomes of continuous positive airway pressure versus oral appliance treatment for obstructive sleep apnea: a randomized 
controlled trial. Am J Respir Crit Care Med 2013 Apr;187(8): 879-887.

53. Almeida FR, Henrich N, Marra C, Lynd LD, Lowe AA, Tsuda H, Fleetham JA, Pliska B, Ayas N. Patient preferences and experiences of CPAP and oral appliances for the treatment of obstructive sleep apnea: a qualitative analysis. Sleep Breath 2013 May;17(2):659-666.

54. Calik MW. Treatments for obstructive sleep apnea. J Clin Outcomes Manag 2016 Apr;23(4):181-192.

55. Gillespie MB, Smith JE, Clarke J, Nguyen SA. Effectiveness of Pillar palatal implants for snoring management. Otolaryngol Head Neck Surg 2009 Mar;140(3):363-368.

56. Lin HC, Friedman M, Chang HW, Lai CC, Chin CH, Lin MC, Pott T, Samuelson C. Effects of Pillar implants for sleepbreathing disorders on middle ear function. Eur Arch Otorhinolaryngol 2013 Aug;270(8):2339-2343.

57. Choi JH, Kim SN. Efficacy of the pillar implant in the treatment of snoring and mild-to-moderate obstructive sleep apnea: a meta-analysis. Laryngoscope 2013 Jan;123(1):269-276.

58. Haytoglu S, Kayabasoglu G, Sezen OS. Comparison of two techniques in simple snoring and obstructive sleep apnea syndrome patients: palatal implant or uvulopalatal flap. Eur J Gen Med 2014;11:179-186.

59. Friedman M, Schalch P, Lin HC, Kakodkar KA, Mazllom N. Palatal implants for the treatment of snoring and obstructive sleep apnea/hypopnea syndrome. Otolaryngol Head Neck Surg 2008 Feb;138(2):209-216.

60. Steward DL, Huntley TC, Woodson BT, Surdulescu V. Palate implants for obstructive sleep apnea: multi-institution, randomized, placebo-controlled study. Otolaryngol Head Neck Surg 2008 Oct;139(4):506-510.

61. Neruntarat C. Long-term results of palatal implants for obstructive sleep apnea. Eur Arch Otorhinolaryngol 2011 Jul;268(7):1077-1080.

62. Blackman A, Foster GD, Zammit G, Rosenberg R, Aronne L, Wadden T, Claudius B, Jensen CB, Mignot E. Effect of liraglutide $3.0 \mathrm{mg}$ in individuals with obesity and moderate or severe obstructive sleep apnea: the SCALE Sleep Apnea randomized clinical trial. Int J Obes 2016 Aug;40(8):1310-1319.

63. Young T, Peppard PE, Taheri S. Excess weight and sleepdisordered breathing. J Appl Physiol (1985) 2005 Oct;99(4): 1592-1599.

64. Lindberg E, Gislason T. Epidemiology of sleep-related obstructive breathing. Sleep Med Rev 2000 Oct;4(5):411-433.

65. Johansson K, Neovius M, Lagerros YT, Harlid R, Rossner S, Granath F, Hemmingsson E. Effect of a very low energy diet on moderate and severe obstructive sleep apnoea in obese men: a randomised controlled trial. BMJ 2009 Dec 3;339:b4609.

66. Kuna ST, Reboussin DM, Borradaile KE, Sanders MH, Millman RP, Zammit G, Newman AB, Wadden TA, Jakicic JM, Wing RR, et al. Long-term effect of weight loss on obstructive sleep apnea severity in obese patients with type 2 diabetes. Sleep 2013 May;36(5):641-649.

67. Tuomilehto H, Seppa J, Uusitupa M, Tuomilehto J, Gylling $\mathrm{H}$. Weight reduction and increased physical activity to prevent the progression of obstructive sleep apnea: a 4-year observational postintervention follow-up of a randomized clinical trial. [corrected]. JAMA Intern Med 2013 May;173(10): 929-930.

68. Tuomilehto H, Seppa J, Uusitupa M, Peltonen M, Martikainen T, Sahlman J, Kokkarinen J, Randell J, Pukkila M, Vanninen E, et al. The impact of weight reduction in the prevention of the progression of obstructive sleep apnea: an explanatory analysis of a 5-year observational follow-up trial. Sleep Med 2014 Mar;15(3):329-335.

69. Epstein LJ, Kristo D, Strollo PJ Jr, Friedman N, Malhotra A, Patil SP, Ramar K, Rogers R, Schwab RJ, Weaver EM, et al. Clinical guideline for the evaluation, management and longterm care of obstructive sleep apnea in adults. J Clin Sleep Med 2009 Jun;5(3):263-276.

70. Qaseem A, Holty JE, Owens DK, Dallas P, Starkey M, Shekelle P. Management of obstructive sleep apnea in adults: a clinical practice guideline from the America College of Physicians. Ann Intern Med 2013 Oct;159(7):471-483.

71. Blonde L, Russell-Jones D. The safety and efficacy of liraglutide with or without oral antidiabetic drug therapy in type 2 diabetes: an overview of the LEAD 1-5 studies. Diabetes Obes Metab 2009 Dec;11(Suppl 3):26-34.

72. Mehta A, Marso SP, Neeland IJ. Liraglutide for weight management: a critical review of the evidence. Obes Sci Pract 2017 Mar;3(1):3-14.

73. Van Can J, Sloth B, Jensen CB, Flint A, Blaak EE, Saris WH. Effects of the once-daily GLP-1 analog liraglutide on gastric emptying, glycemic parameters, appetite and energy metabolism in obese, non-diabetic adults. Int J Obes (Lond) 2014 Jun;38(6):784-793.

74. Guilleminault C, Powell N, Bowman B, Stoohs R. The effect of electrical stimulation on obstructive sleep apnea syndrome. Chest 1995 Jan;107(1):67-73.

75. Steier J, Seymour J, Rafferty GF, Jolley CJ, Solomon E, Luo Y, Man WD, Polkey MI, Moxham J. Continuous transcutaneous submental electrical stimulation in obstructive sleep apnea: a feasibility study. Chest 2011 Oct;140(4):998-1007.

76. Eastwood PR, Barnes M, Walsh JH, Maddison KJ, Hee G, Schwartz AR, Smith PL, Malhotra A, McEvoy RD, Wheatley JR, et al. Treating obstructive sleep apnea with hypoglossal nerve stimulation. Sleep 2011 Nov;34(11):1479-1486.

77. KezirianEJ,GodingGSJr,MalhotraA,O'DonoghueFJ,ZammitG, Wheatley JR, Catcheside PG, Smith PL, Schwartz AR, Walsh JH, et al. Hypoglossal nerve stimulation improves obstructive sleep apnea: 12-month outcomes. J Sleep Res 2014 Feb;23(1):77-83.

78. Strollo PJ Jr, Soose RJ, Maurer JT, de Vries N, Cornelius J, Froymovich O, Hanson RD, Padhya TA, Steward DL, Gillespie $\mathrm{MB}$, et al. Upper-airway stimulation for obstructive sleep apnea. N Engl J Med 2014 Jan;370(2):139-149.

79. Van de Heyning PH, Badr MS, Baskin JZ, Cramer Bornemann MA, De Backer WA, Dotan Y, Hohenhorst W, Knaack L, Lin HS, Maurer JT, et al. Implanted upper airway stimulation device for obstructive sleep apnea. Laryngoscope 2012 Jul;122(7):1626-1633.

80. Kezirian EJ, Boudewyns A, Eisele DW, Schwartz AR, Smith PL, Van de Heyning PH, De Backer WA. Electrical stimulation of the hypoglossal nerve in the treatment of obstructive sleep apnea. Sleep Med Rev 2010 Oct;14(5):299-305.

81. Strollo PJ, Gillespie MB, Soose RJ, Maurer JT, de Vries N, Cornelius J, Hanson RD, Padhya TA, Steward DL, Woodson BT, et al. Upper airway stimulation for obstructive sleep apnea: durability of the treatment effect at 18 months. Sleep 2015 Oct;38(10):1593-1598.

82. Soose RJ, Woodson BT, Gillespie MB, Maurer JT, de Vries N, Steward DL, Strohl KP, Baskin JZ, Padhya TA, Badr MS, et al. Upper airway stimulation for obstructive sleep apnea: selfreported outcomes at 24 months. J Clin Sleep Med 2016 Jan;12(1):43-48. 
83. Woodson BT, Gillespie MB, Soose RJ, Maurer JT, de Vries N, Steward DL, Baskin JZ, Padhya TA, Lin HS, Mickelson S, et al. Randomized controlled withdrawal study of upper airway stimulation on OSA: short- and long-term effect. Otolaryngol Head Neck Surg 2014 Nov;151(5):880-887.

84. Woodson BT, Soose RJ, Gillespie MB, Strohl KP, Maurer JT, de Vries N, Steward DL, Baskin JZ, Badr MS, Lin HS, et al. Three-year outcomes of cranial nerve stimulation for obstructive sleep apnea: the STAR trial. Otolaryngol Head Neck Surg 2016 Jan;154(1):181-188.

85. Heinzer RC, Stanchina ML, Malhotra A, Jordan AS, Patel SR, Lo YL, Wellman A, Schory K, Dover L, White DP. Effect of increased lung volume on sleep disordered breathing in patients with sleep apnoea. Thorax 2006 May;61(5):435-439.

86. Morrell MJ, Arabi Y, Zahn B, Badr MS. Progressive retropalatal narrowing preceding obstructive apnea. Am J Respir Crit Care Med 1998 Dec;158(6):1974-1981.

87. Berry RB, Kryger MH, Massie CA. A novel nasal expiratory positive airway pressure (EPAP) device for the treatment of obstructive sleep apnea: a randomized controlled trial. Sleep 2011 Apr;34(4):479-485.

88. Riaz M, Certal V, Nigam G, Abdullatif J, Zaghi S, Kushida CA, Camacho M. Nasal expiratory positive airway pressure devices (Provent) for OSA: a systematic review and metaanalysis. Sleep Disorders 2015;2015:734-798.

89. Walsh JK, Griffin KS, Forts EH. A convenient expiratory positive airway pressure nasal device for the treatment of sleep apnea in patients non-adherent with continuous positive airway pressure. J Clin Sleep Med 2011 Feb;12(2):147-152.

90. Cartwright RD. Effect of sleep position on sleep apnea severity. Sleep 1984;7(2):110-114.

91. Joosten SA, Hamza K, Sands S, Turton A, Berger P, Hamilton G. Phenotypes of patients with mild to moderate obstructive sleep apnoea as confirmed by cluster analysis. Respirology 2012 Jan;17(1):99-107.

92. Lee $\mathrm{CH}$, Kim DK, Kim SY, Rhee CS, Won TB. Changes in site of obstruction in obstructive sleep apnea patients according to sleep position: a DISE study. Laryngoscope 2015 Jan;125(1):248-254.

93. Maanen JP, Richard W, Van-Kesteren ER, Ravesloot MJ, Lama DM, Hilgevoord AA, de Vries N. Evaluation of a new simple treatment for positional sleep apnoea patients J Sleep Res 2012 Jun;21(3):322-329.

94. Levendowsli DJ, Seagraves S, Popovic D, Westbrook PR. Assessment of a neck-based treatment and monitoring device for positional obstructive sleep apnea. J Clin Sleep Med 2014 Aug;10(8):863-871.
95. Jackson M, Collins A, Berlowitz D, Howard M, O’Donoghue F, Barnes M. Efficacy of sleep position modification to treat positional obstructive sleep apnea. Sleep Med 2015 Apr;16(4): 545-552.

96. Mason M, Welsh EJ, Smith I. Drug therapy for obstructive sleep apnoea in adults. Cochrane Database Syst Rev 2013 May;(5):CD003002.

97. Eckert DJ, Owens RL, Kehlmann GB, Wellman A, RahangdaleS, Yim-Yeh S, White DP, Malhotra A. Eszopiclone increases the respiratory arousal threshold and lowers the apnoea/hypopnoea index in obstructive sleep apnoea patients with a low arousal threshold. Clin Sci 2011 Jun;120(12):505-514.

98. Edwards BA, Connolly JG, Campana LM, Sands SA, Trinder JA, White DP, Wellman A, Malhotra A. Acetazolamide attenuates the ventilatory response to arousal in patients with obstructive sleep apnea. Sleep 2013 Feb;36(2):281-285.

99. Edwards BA, Sands SA, Eckert DJ, White DP, Butler JP, Owens RL, Malhotra A, Wellman A. Acetazolamide improves loop gain but not the other physiological traits causing obstructive sleep apnoea. J Physiol 2012 Mar;590(Pt 5):1199-1211.

100. Farabi SS, Prasad B, Quinn L, Carley DW. Impact of dronabinol on quantitative electroencephalogram (qEEG) measures of sleep in obstructive sleep apnea syndrome. J Clin Sleep Med 2014 Jan;10(1):49-56.

101. Prasad B, Radulovacki MG, Carley DW. Proof of concept trial of dronabinol in obstructive sleep apnea. Front Psychiatry 2013;4:1.

102. Calik MW, Carley DW. Cannabinoid type 1 and type 2 receptor antagonists prevent attenuation of serotonin-induced reflex apneas by dronabinol in Sprague-Dawley rats. PLoS One 2014 Oct;9(10):e111412.

103. Deacon NL, Jen R, Li Y, Malhotra A. Treatment of obstructive sleep apnea. prospects for personalized combined modality therapy. Ann Am Thorac Soc 2016 Jan;13(1):101-108.

104. Shin W, Jen R, Li Y, Malhotra A. Tailored treatment strategies for obstructive sleep apnea. Respir Investig 2016 Jan;54(1): 2-7.

105. Dieltjens M, Vroegop AV, Verbruggen AE, Wouters $K$, Willemen M, De Backer WA, Verbraecken JA, Van de Heyning $\mathrm{PH}$, Braem MJ, de Vries N, et al. A promising concept of combination therapy for positional obstructive sleep apnea. Sleep Breath 2015 May;19(2):637-644.

106. Wellman A, Edwards BA, Sands SA, Owens RL, Nemati S, Butler J, Passaglia CL, Jackson AC, Malhotra A, White DP. A simplified method for determining phenotypic traits in patients with obstructive sleep apnea. J Appl Physiol (1985) 2013 Apr;114(7):911-922. 